\title{
PERBANDINGAN VARIASI BAKTERI STARTER TERHADAP NILAI KALOR BIOGAS DARI SAMPAH ORGANIK
}

\author{
Subur Mulyanto ${ }^{1 *}$, Ida Bagus Dharmawan ${ }^{2}$ Iqbal Adzanni $^{3}$ \\ ${ }^{1.2}$ Jurusan Teknik Mesin, Politeknik Negeri Balikpapan \\ ${ }^{3}$ Mahasiswa Jurusan Teknik Mesin, Politeknik Negeri Balikpapan \\ *e-mail: subur.mulyanto@poltekba.ac.id,
}

\begin{abstract}
Biogas one of the renewable energy that can be used as an alternative to reduce the use of fossil energy, raw materials of biogas energy is garbage and organic waste overflow crowds around us, the rest of the vegetable from market, animal dung and human waste, are some examples of junk and organic waste which can be used as raw material for biogas. This study, the biogas produced from organic waste materials and used addition of bacterial starter, the EM4 purchased from the farm shop. The study was conducted to compare the calorific value of the biogas produced by the variation of the addition of EM4 stater. Variations addition of EM4 done on the variation of $25 \mathrm{ml}, 50 \mathrm{ml}$ and $75 \mathrm{ml} \mathrm{per} 400 \mathrm{ml}$ of organic waste materials that have been mixed with water at a ratio of 2: 1. Calorific value generated is the variation of $876.21 \mathrm{~J} /$ liter, $863.01 \mathrm{~J} /$ liter, $75 \mathrm{ml}$ of $1131.31 \mathrm{~J} /$ liter respectifly.
\end{abstract}

Keywords :Biogas, Digester, Starter, EM4, Calorific value

\begin{abstract}
Abstrak
Biogas salah satu energi terbarukan yang dapat digunakan sebagai salah satu alternatif mengurangi penggunaan energi fosil, bahan baku dari energi biogas ini adalah sampah dan limbah organik yang banyak melimpah di sekitar kita, sisa sayuran pasar, kotoran ternak, dan kotoran manusia, merupakan beberapa contoh sampah dan limbah organik yang dapat di gunakan sebagai bahan baku biogas. Dalam penelitian ini biogas diproduksi dari bahan baku sampah organik dengan penambahan bakteri starter, yaitu EM4 yang dibeli dari toko pertanian. Penelitian ini bertujuan untuk mengetahui perbandingan nilai kalori biogas yang dihasilkan dengan variasi penambahan stater EM4. Variasi penambahan EM4 dilakukan pada variasi $25 \mathrm{ml}, 50 \mathrm{ml}$ dan $75 \mathrm{ml}$ setiap $400 \mathrm{ml}$ bahan sampah organik yang sudah tercampur dengan air pada perbandingan $2: 1$. Nilai kalori yang dihasilkan yaitu pada variasi $25 \mathrm{ml}$ sebesar $876,21 \mathrm{~J} /$ liter, pada variasi $50 \mathrm{ml}$ sebesar $863,01 \mathrm{~J} /$ liter dan pada variasi $75 \mathrm{ml}$ sebesar $1131,31 \mathrm{~J} /$ liter
\end{abstract}

Kata kunci :Biogas, Digester, Starter, EM4,Nilai Kalor

\section{Pendahuluan}

Biogas salah satu energy terbarukan yang dapat digunakan sebagai salah satu alternative mengurangi penggunaan energy fosil,bahan baku dari energi biogas ini adalah sampah dan limbah organik yang banyak melimpah di sekitar kita, sisa sayuran pasar, kotoran ternak, dan kotoran manusia, merupakan beberapa contoh sampah dan limbah organik yang dapat di gunakan sebagai bahan baku biogas.

Biogas adalah gas yang dihasilkan oleh aktivitas anaerobic atau fermentasi dari bahan organic termasuk diantaranya :kotoran manusia dan hewan, sampah sayuran [1]. Perbandingan campuran sampah, limbah, kotoran organic terhadap campuran bakteri sangat berpengaruh terhadap gas metan (CH4) yang dihasilkan. Biogas yang menghasilkan gas metana (CH4) dan karbondioksida (CO2) dan sejumlah kecil nitrogen (Nitrogen), ammonia (NH3), sulfur dioksida (SO2), hidrogen sulfide $(\mathrm{H} 2 \mathrm{~S})$ serta hydrogen $(\mathrm{H})$ danOksigen (O2) yang kandungannya sangat kecil[2]. Energi yang terkandung dalam biogas tergantung dari konstrentasi metana (CH4) semakin tinggi kandungan 
metana makin besar kandungan energi (nilai kalor) dan semakin kecil kandungan metana semakin kecil nilai kalor.

Dekomposisi bahan bahan organik dibawah ini kondisi kondisi anaerobik menghasilkan suatu gas yang sebagian besar terdiri atas campuran campuran metan dan arang dioksida. Gas ini dikenal sebagai rawa ataupun biogas. Campuran gas ini adalah hasil daripada fermentasi atau peranan anaerobic disebabkan sejumlah besar jenis organisme mikro, terutama bakteri metan. Suhu yang baik untuk proses fermentasi ini adalah dari 300 $\mathrm{C}$ hingga kira kira $500 \mathrm{C}$ [4].

Salah satu lemak menghasilkan 1,25 liter biogas, tekanan atmosfirik, yang terdiri dari $68 \% \quad \mathrm{CH} 4$ dan $32 \% \mathrm{CO} 2$, tergantung daripada komposisi bahan bahan yang dipakai, suhu dan lama dekomposisi, dapat dicatat variasi yang besar mengenai komposisi gas yang diperoleh. Biogas mempunyai komposisi sebagaimana terlihat dari tabel 1.1.

Tabel 1 Komposisi Biogas [3]

\begin{tabular}{|l|l|l|}
\hline Penjelasan & Rumus & Persentase \\
\hline Metan & $\mathrm{CH}_{4}$ & $55-65 \%$ \\
\hline Karbondioksida & $\mathrm{CO}_{2}$ & $36-45 \%$ \\
\hline Nitrogen & $\mathrm{N}_{2}$ & $0-3 \%$ \\
\hline Hidrogen & $\mathrm{H}_{2}$ & $0-1 \%$ \\
\hline Oksigen & $\mathrm{O}_{2}$ & $0-1 \%$ \\
\hline HidrogenSulfida & $\mathrm{H}_{2} \mathrm{~S}$ & $0-1 \%$ \\
\hline
\end{tabular}

\subsection{EM-4 (effective microorganism-4)}

Pada tahun 1980-an, Prof. Dr. Teruo Higa dari University of The Ryukus, Okinawa, Jepang telah mengadakan penelitian terhadap sekelompok mikroorganisme yang dengan efektif dapat bermanfaat dalam memperbaiki kondisi tanah, menekan pertumbuhan mikroba yang menimbulkan penyakit dan memperbaiki efisiensi penggunaan bahan organik oleh tanaman. Kelompok mikroorganisme tersebut disebut dengan Effective Microorganisms yang disingkat EM. Teknologi EM dikembangkan untuk menunjang pembangunan pertanian ramah lingkungan, menekan penggunaan pupuk kimia dan pestisida dengan sistem alami yang akhirnya dapat meningkatkan produktivitas tanah, mengurangi biaya produksi dan menghasilkan bahan pangan yang bebas bahan kimia sehingga bersih dan sehat untuk di konsumsi.Teknologi EM yang sudah mulai akrab dengan masyarakat adalah Effective Microorganisms-4 biasa disingkat EM4 adalah suatu kultur campuran beberapa mikroorganisme yang dapat digunakan sebagai inokulan mikroba yang berfungsi sebagai alat pengendali biologis. Mikroorganisme tersebut berfungsi dalam lingkungan hidup tanaman sebagai penekan dan pengendali perkembangan hama dan penyakit.

\subsection{Hal yang Perlu Diperhatikan Pada Saat Proses Fermentasi}

Keberhasilan proses pencernaan dalam digester sangat ditentukan oleh desain dan pengaturan digester itu sendiri, beberapa hal yangperlu diperhatikan dalam proses:

\section{Pengadukan}

Proses pengadukan akan sangat menguntungkan karena apabila tidak diaduk solid akan mengendap pada dasar tangki dan akan terbentuk busa pada permukaan yang akan menyulitkan keluarnya gas. Masalah tersebut terjadi lebih besar pada proses yang menggunakan bahan baku limbah sayuran dibandingkan yang menggunakan kotoran ternak . Pada sistem kontinyu masalah ini lebih kecil karena pada saat bahan baku dimasukkan akan memecahkan busa pada permukaan seolah-olah terjadi pengadukan - Pada digester yang berlokasi di Eropa dimana pemanasan diperlukan jika proses dilakukan pada musim dingin, sirkulasi udara juga merupakan proses pengadukan. 


\section{Kontrol temperatur}

Pada daerah panas, penggunaan atap akan membantu agar temperatur berada pada kondisi yang ideal, tetapi pada daerah dingin akan menyebabkan masalah. Langkah yang umumnya diambil yaitu dengan melapisi tangki dengan tumpukan jerami atau serutan kayu dengan ketebalan 50 sampai $100 \mathrm{~cm}$, lalu dilapisi dengan bungkus tahan air, jika masih kurang maka digunakan koil pemanas. Temperatur digester yang tinggi akan lebih rentan terhadap kerusakan karena fluktuasi temperatur, untuk itu diperlukan pemeliharaan yang seksama.

\section{Koleksi gas}

Pengumpulan biogas yang dihasilkan menggunakan drum yang dipasang terbalik, drum harus dapat bergerak sehingga dapat disesuaikan dengan volume gas yang diperlukan. Biogas akan mengalir melalui lubang kecil di atas drum. Digunakan valve searah untuk mencegah masuknya udara luar ke dalam tangki digester yang akan merusak aktivitas bakteri dan memungkinkan terjadinya ledakan di dalam drum. Pada instalasi yang besar diperlukan kontrol pengukuran berat dan tekanan yang baik.

\section{Perbandingan C-N Bahan}

Rasio C-N adalah perbandingan kadar karbon $(\mathrm{C})$ dan kadar Nitrogen $(\mathrm{N})$ dalam satuan bahan. Semua mahluk hidup terbuat dari sejumlah besar bahan Karbon (C) dan Nitrogen (N) dalam jumlah kecil.Untuk menjamin semuanya berjalan lancar, unsur-unsur nutrisi yang dibutuhkan mikroba harus tersedia secara seimbang. Ternak ruminansia seperti sapi, kambing dan domba rata-rata lebih lama dalam menghasilkan biogas dibandingkan dengan ternak non ruminansia. Lamanya produksi biogas disebabkan oleh mutu pakan yang lebih rendah, sehingga rasio C-Nnya tinggi akibatnya perkembangan mikroba pembentuk gas lebih lama dibandingkan yang bermutu tinggi. Tinggi rendahnya mutu ini tergantung pada nilai $\mathrm{N}$ (nitrogen) di dalam ransum. Namun demikian nilai $\mathrm{N}$ juga tergantung pada $\mathrm{C}$ (karbon). Jadi, perbandingan $\mathrm{C}$ dan $\mathrm{N}$ akan menentukan lama tidaknya proses pembentukan biogas [1]

5. Posisi Digester

Digester biogas yang dibangun di atas permukaan tanah harus terbuat dari baja untuk menahan tekanan, sedangkan yang dibangun di bawah tanah umumnya lebih sederhana dan murah. Namun, dari segi pemeliharaan, digester di atas permukaan akan lebih mudah dan digester dapat ditutup lapisan hitam yang berfungsi untuk menangkap panas matahari.

\subsection{Kapasitas Kalor}

Kapasitas kalor adalah banyaknya kalor yang dibutuhkan untuk menaikkan suhu seluruh benda sebesar satu derajat, adapun rumus kapasitas kalor adalah:

$\mathrm{C}=\mathrm{Q} / \mathrm{T}$ atau $\mathrm{Q}=\mathrm{C} . \mathrm{T}$

keterangan:

$\mathrm{C}=$ Kapasitas Kalor

$\mathrm{Q}=$ Qalor

$\Delta \mathrm{T}=$ Kenaikan Suhu

Kalor Q yang diserap oleh gas untuk menaikkan suhunya dapat dilakukan pada volume tetap (isohorik) atau tekanan tetap (isobarik).Oleh karena itu ada dua jenis kapasiyas kalor gas,yaitu kapasitas kalor gas pada tekanan tetap,Cp, dan kapasitas kalor pada volume tetap $\mathrm{Cv}$,

$$
\begin{aligned}
& c v=Q v / \Delta T \\
& c p=Q p / \Delta T
\end{aligned}
$$

Hubunagan $\mathrm{Cp}$ dan $\mathrm{Cv}$ dinyatakan oleh persamaan Mayer,

$$
\mathrm{Cp}-\mathrm{Cv}=\mathrm{nR}
$$

Dengan $\mathrm{R}=8,31 \mathrm{~J} / \mathrm{mol} \mathrm{K}$ dan $\mathrm{n}=$ jumlah mol gas ( mol )

Selain kapasitas kalor sering juga dihunakan kapasitas kalor molar gas dan 
kalor jenis gas.Kapasitas kalor molar $(\mathrm{Cm})$,dirumuskan oleh :

$$
\mathrm{Cm}=\mathrm{Qp} / \mathrm{n} \Delta \mathrm{T}
$$

Kapasitas kalor molar pada volume tetap $(\mathrm{Cv}, \mathrm{m})$ dan kapasitas kalor molar pada tekanan tetap $(\mathrm{Cp}, \mathrm{m})$ dirumuskan oleh :

$$
\begin{aligned}
& \mathrm{cv}, \mathrm{m}=\mathrm{Qv} / \mathrm{n} \Delta \mathrm{T} \\
& \mathrm{cp}, \mathrm{m}=\mathrm{Qp} / \mathrm{n} \Delta \mathrm{T}
\end{aligned}
$$

Hubungan cp dan cv dinyatakan oleh:

$$
\mathrm{cp}, \mathrm{m}-\mathrm{cv}, \mathrm{m}=\mathrm{R}
$$

\subsection{Kalorimeter}

Kalorimeter adalah suatu sistem tersisolasi (tidak ada pertukaran materi maupun energi dengan lingkungan diluar kalorimeter). Dengan demikian, semua kalor yang di bebaskan oleh reaksi yang terjadi di dalam calorimeter, tidak ada yang terbuang dari Kalorimeter. Dengan mengukur kenaikan suhu di dalam Kalorimeter, kita dapat menentukan jumlah kalor yang di serapair serta perangkat Kalorimeter berdasarkan rumus:

$$
\mathrm{q}=\mathrm{m} \times \mathrm{c} \times \Delta \mathrm{t}
$$

keterangan :

$\mathrm{Q}=$ nilai kalor (joule/liter)

$\mathrm{m}=$ massa Air (gram)

$\mathrm{c}=$ kalor jenis $(\mathrm{j} / \mathrm{g} . \mathrm{oc})$

$\Delta \mathrm{t}=$ perubahan suhu $(\mathrm{oc})$

Dikarenakan tidak adanya kalor yang terbuang ke lingkungan, maka kalor reaksi sama dengan kalor yang diserap air, tetapi tandanya berbeda.

Dalam penelitian dimaksudkan untuk mencari perbandingan antara bakteri starter yang dicampur dengan bahan baku yaitu sampah organik, dengan parameter nilai kalori daripada biogas yang dihasilkan.

\section{Metoda Penelitian}

Reaktor digester yang digunakan dlampenelitian ini adalah tipe fixed dome dan bahan yang akan difermentasi yaitu dari sampah organik yang diberi penambahan stater EM4 yang dibeli di toko pertanian.

Dalm penelitian ini akan dilakukan variasi penambahan stater EM4 untuk di ukur kalorinya. Setelah difermentasi dan dipatkan hasil biogas dilakukan uji bakar terlebih dahulu, yaitu dengan menggunakan pematik api pada saat kran gas dibuka, jika gas sudah terbakar maka baru dilakukan uji kalri dengan menggunakan kalorimeter. Dari hasil variasi penambahan stater EM4 dilihat perbandingannya terhadap nilai kalori pada biogas yang dihasilkan.

\section{Hasil dan Pembahasan}

\subsection{Volume Hasil Biogas}

Volume gas harian diukur berdsarkan jumlah kenaikan slurry pada pipa pengaman digester, adapun perhitungan yang digunakan sebagai berikut:

$$
\mathrm{V}=\pi \times \mathrm{r} 2 \times \mathrm{t}
$$

Keterangan:

$\mathrm{V}=$ volume

$\pi=3.14,22 / 7$

$\mathrm{r} 2=$ jari jari pipa

$\mathrm{t}=$ tinggi perbedaan slurry

Dari hasil perhitungan di atas lalu di jumlahkan dengan volume ruang kosong digester yaitu 1,325 liter, maka di dapatkan hasil seperti gambar berikut




Berdasarkan hasil grafik di atas menunjukan bahwa pada hari ke 2 biogas sudah mengalami kenaikan dan keterlambatan dilihat pada digester 1 yang ditambahkan $25 \mathrm{ml}$ EM4, ini disebabkan karena aktifitas EM-4 yang terdiri atas Lactobacillus, Actinomycetes, dan jamur. Fungsi mikro-organisme diduga melakukan delignifikasi, menurunkan derajat polimerisasi selulosa, dan hidrolisis hemiselulosa. Penambahan EM-4 mempercepat degradasi selulosa, hemiselulosa dan lignin menjadi senyawa yang dibutuhkan oleh mikroorganisme penghasil biogas, sehingga produksi biogas meningkat. pada masing masing digester berpengaruh pada volume biogas dan Proses penggilingan dapat memecah dinding sel tumbuhan dengan lebih baik sehingga bakteri akan lebih mudah mencerna atau mendekomposisi kandungan senyawa di dalam sel [5]. Kenaikan volume biogas ini terus berlanjut sampai hari ke 16 dimana semua digester mengalami puncak kenaikan volume dimna pada digester 1 menghasilkan volume sebanyak 1.441 liter dan pada digester 2 dihasilkan gas puncak pada hari ke 17 sebanyak 1.462 liter dan pada herigen 3 menghasilkan gas puncak di hari ke 16 sebanyak 1.488 liter dan pada hari ke 18 produksi mengalami penurunan ketika bakteri metan memasuki deathpase. Deathpase terjadi karena kurangnya nutrient atau sumber karbon yang di dapat dari substrat, sehingga pertumbuhan bakteri metan akan menurun dan semakin banyak bakteri yang mati [3]. Berkurangnya jumlah bakteri menyebabkan biogas yang diproduksi juga semakin sedikit.

\subsection{Nilai Kalor Biogas}

Penghitungan nilai kalor biogas berdasarkan persamaan dibawah ini dilakukan setelah volume biogas tidak mengalami peningkatan lagi atau sudah mencapai kondisistatis. Pengukuran yang dilakukan pada hari ke 1 sampai hari ke 18 dimana semua variasi sudah mengalami kondisi statis.Perhitungan nilai kalor biogas dilakukan dengan percobaan untuk memanaskan air sebanyak 100 gram kemudian dilakukan pengukuran peningkatan suhu sampai nyala api padam, yang berarti bahwa biogas sudah habis terbakar. Dengan menggunakan metode perhitungan (1) maka hasil perhitungan nilai kalor tiap variasi dapat dilihat pada table 2 di bawah ini

Tabel 2 Nilai Kalor Tiap Variasi

\begin{tabular}{|c|c|c|c|c|c|c|}
\hline Var & $\begin{array}{c}\mathrm{M}_{\text {air }} \\
(\mathrm{g})\end{array}$ & $\begin{array}{c}\mathrm{T}_{1} \\
\left({ }^{\circ} \mathrm{C}\right)\end{array}$ & $\begin{array}{c}\mathrm{T}_{2} \\
\left({ }^{\mathrm{O}} \mathrm{C}\right)\end{array}$ & $\begin{array}{c}\mathrm{t} \\
\left({ }^{\mathrm{O}} \mathrm{C}\right)\end{array}$ & $\begin{array}{c}\text { Vol. } \\
\text { bioga } \\
\mathrm{s} \\
(\text { liter })\end{array}$ & $\begin{array}{c}\text { kalor } \\
(\mathrm{j} / \text { liter })\end{array}$ \\
\hline 1 & 100 & 28 & 31 & 3 & 1,438 & 876.21 \\
\hline 2 & 100 & 28 & 31 & 3 & 1,460 & 863.01 \\
\hline 3 & 100 & 28 & 32 & 4 & 1,485 & 1131.31 \\
\hline
\end{tabular}

Berdasarakan hasil penghitungan di atas di dapatkan hasil nilai kalor tertinggi pada digester 3 yaitu sebanyak 1131.31 joule/liter jumlah $\mathrm{CH} 4$ yang dihasilkan pada saat proses fermentasi sangat berpengaruh terhadap hasil nilai kalor. Nilai kalor terendah di dapat pada hasil fermentasi pada digester 2 meskipun penambahan EM4 pada digester 2 lebih banyak daripada digester 1 tetapi berbanding terbalik pada nilai kalor yang dihasilkan. Pada rumus tersebut dapat di lihat pada rumus kalor diatas bahwa nilai kalor berbanding terbalik terhadap volume gas yang dihasilkan, itulah hal yang menyebabkan digester 2 memiliki nilai kalor lebih rendah dari digester 1 yang menghasilkan nilai kalor sebanyak 876.21 joule/liter, EM4 dapat membantu mempercepat proses menghasilkan biogas ini dikarenakan Bakteri Fotosintetik mampu mempercepat menghasilkan senyawa senyawa seperti, asam amino, asam nukleik, zat bioaktif dan Bakteri Asam Laktat, bakteri ini dapat menekan pertumbuhan mikroorganisme yang merugikan, meningkatkan percepatan perombakan bahan organik; 
menghancurkan bahan organik seperti lignin dan selulosa yang ada pada tahapan hidrolisis serta memfermentasikannya tanpa menimbulkan senyawa beracun yang ditimbulkan dari pembusukan bahan organik, Jamur fermentasi (Aspergillus dan Penicilium) menguraikan bahan secara cepat untuk menghasilkan alkohol, ester dan zat-zat anti mikroba pada tahapan hidrolisis. Rasio C/N pada sampah organik membantu terhadap jumlah nilai kalor yang dihasilkan umumnya berkisar 12,525 , ini sangat menentukan kehidupan dan aktivitas mikroorganisme didalam digester. Posisi digester diatas permukaan tanah ini sangat rentan terhadap suhu sekitar ini juga berdampak pada bakteri yang berada di dalam digester dimana bakteri seperti Steptococci,Bacteriodes, Enterobactericeae ,Desulfovibrio,Mathanobacterium,Mathan obacillus,Methanosacaria,danMethanococ cus sangat rentan pada tempratur yang tinggi maka di perlukan control tempratur guna menstabilkan suhu di dalam digester, serta proses pengadukan akan sangat menguntungkan karena apabila tidak diaduk dengan baik maka sampah yang ada di dalam permukaan digester akan menyulitkan keluarnya gas methan yang di hasilkan [5].

\section{Kesimpulan}

Penambahan EM 4 dilakukan pada setelah campuran antara sampah organic dan air (1:1) di masukan kedalam digester setalah itu digester di bolak balik agar EM 4 dapat tercampur.

Pengaruh penambahan EM 4 sebagai starter terhadap volume produksi biogas menunjukkan nilai tertinggi sebesar 1.,485 liter untuk variasi pada digester 3 dengan penambahan starter $75 \mathrm{ml}$. Sedangkan produksi terendah diperoleh dengan penambahan EM 4 sebagai starter yaitu sebanyak $25 \mathrm{ml}$ sebesar 1,438 liter. Kadar $\mathrm{CH} 4$ sangat berpengaruh terhadap nilai kalor semakin tinggi nilai kalor yang di hasilkan maka akan menghasilkan nilai kalor yang tinggi pula, untuk perhitungan terhadap nilai kalor menunjukkan nilai kalor biogas terbesa radalah 1131.31 joule/liter untuk variasi digester 3 dengan penambahan starter EM4 sebanyak $75 \mathrm{ml}$. Sedangkan nilai kalor terendah adalah 863.01 joule/liter untuk variasi digester 2 . Pada temperature ekstraksi $70^{\circ} \mathrm{C} \quad \mathrm{s} . / \mathrm{d}$. $90^{0} \mathrm{C}$.

\section{Saran}

Penelitian selanjutnya dapat melakukan fermentasi lebih dini dikarenakan waktu fermentasi yang cukup lama dan melakukan pengadukan di dalam digester agar dapat menghasilkan biogas yang optimal, serta dapat menerapkan hasil biogas di gunakan dalam mesin pembangkit dan megukur nilai efektivitas biogas dengan bahan bakar lain.

\section{DaftarPustaka}

[1]Haryati, Tuti. 2006. Biogas :Limbah Peternakan yang Menjadi Sumber Energi Alternatif, Bogor Heyne, K. (1988). Tumbuhan berguna Indonesia, Yayasan Sarana WanaJaya :Diedarkan oleh Koperasi Karyawan, DepartemenKehutanan.

[2] Hardyanti,Nurandan, Sutrisno,Endro. 2007. UjiPembuatan Biogas Dari Kotoran Gajah DenganVariasiPenambahan Urine Gajah Dan Air, Indonesia

[3]DewidanSiagian. 1992. The Potential of Biomass Residues as Energy Sources in Indonesia

[4]Pratiwi, D.A., Maryati, Sri Srikini., Suharno., S. Bambang., 2012. Biologiuntuk SMA/MA kelas X, (48-49, 56), Jakarta: Erlangga.

[5] Harmidi, Nurkholi. 2011. Peningkatan Kualitas Bahan Bakar Biogas Melalui Proses Pemurnian dengan Zeolit Alam 